\title{
Assessment of Accessibility and Utilization of Information and Communication Technology (ICT) for Effective Teaching of Biological Science in Secondary Schools
}

Olusesan A. Adelabu

\author{
Department of Microbiology, University of Fort Hare, South Africa \\ 201409080@ufh.ac.za \\ Prof Emmanuel O.Adu
}

School of Continuing and General Education, University of Fort Hare, South Africa,

eadu@ufh.ac.za

\section{Doi:10.5901/mjss.2014.v5n23p1439}

\begin{abstract}
This study investigated information and communication technology (ICT) accessibility and utilization for effective teaching of biological science in secondary schools in Ibadan-north Local Government Area of Oyo State. A 20 item instruments of (ICTFAQ) and (ICTFUQ) were adopted for this study. The study sampled 72 biological science teachers in selected secondary schools in Ibadan-north, Oyo State. The descriptive statistics was adopted in analyzing the data collected for this study, while the generated hypotheses were tested at 0.05 level of significance, using t-test. Hence, the results revealed that ICT facilities were not available, and accessed by teachers in secondary schools in Ibadan-north. In addition, it was revealed that biological science teachers in these schools do not also have the proper skills required to utilize ICT for effective teaching of the subject. Conclusively, recommendations on ways of solving the problem were implemented for further consideration and execution by the government authorities, and the stakeholders.
\end{abstract}

Keywords: ICT, biological science, utilization, accessibility, execution, effective teaching

\section{Introduction}

The emergence of information and communication technology (ICT) has totally transformed the way we access, process, exchange, store, retrieve and disseminate information within organizations and/or across the globe whether it is in vocal, pictorial, textual numeric, or macro-electric based hence ICT is now a topical issue in Nigeria. Globally, the evolution of ICT dates back to 1823, when Charles Babbage, a professor of mathematics invented the Analytical Engine. The design comprised of four components for performing the basic functions of input, output, processing and storage (Caselli, 1999).

As new concepts of learning have evolved, teachers are expected to facilitate learning and make it meaningful to individual learners rather than just to provide abstract knowledge and skills (Valcke and van Braak 2008). Modern developments of innovative technologies has provided new possibilities for teaching professions, but at the same time have placed more demands on teacher to learn how to use these new technologies in their teaching (Robinson and Latchem, 2003) These challenges ask teacher to continuously retrain themselves and acquire new knowledge and skills while maintaining their job (Carlson and Gadio, 2002). ICT encompass a range of technologies and application systems of microprocessors that have had profound impact on the society and its way of life. The revolution of information and communication technology (ICT) is drastically influencing the nature of learning and the production of knowledge, hence transforming the globe in unprecedented trend (Holloway, 2003). This has facilitated the paradigm shift from the traditional instructional material or traditional pedagogical methods to a more modern and innovative technological based teaching and learning methods. The impact of ICT is becoming more pronounced worldwide. Such that rarely is anything mentioned in any area of human endeavors without reference to this type of technology. Information and communication technology refers to the process of gathering accessing and dissemination of data for an enhanced learning (Miller and Akume,2009) which is daily giving rise to new concepts and ideas, innovation and invention, and making impact not only in the industries/businesses but also in the education sector. ICT has simplified education through the application of electronics media, internet etc. (Ndukwe, 2006).

A significant milestone in the development of the ICT industry in Nigeria is the formulation of a National Information Technology Policy (NITP), which was approved in March, 2001 by the Federal Executive Council. With the enactment of 
this policy came the establishment of an implementing agency-the National Information Technology Development Agency (NITDA) in April 2001. This agency is charged with the responsibility of implementing Nigeria's IT policy "as well as promotes the healthy growth and development of the IT industry in Nigeria. (Adu et al. 2014)

Today, organizations such as educational/research institutions as well as individuals embrace the usage of internet for accurate and up-to date information and expansion of their horizon. Online collaborator, which refers to sharing of information, working or trading with various people at different places via the internet, is becoming common practice globally (Arunachalam, 2005). The use of computer is continually gaining grounds in many aspects of human endeavors. Hence, ICT revolutional trend has transformed the global perception on the way we think and everyday application of our daily task. Subsequently, the effects of ICT on every human endeavour are so dramatic in speed and performance that it's been viewed as the back done and information super highway of our modern lives (Onyemah, 2009).

\subsection{Purpose of the Study}

The purpose of this study was to investigate into ICT accessibility and utilization in selected secondary schools in Ibadannorth Local Government Area of Oyo State. Specifically, the study sought to:

1. Establish ICT facilities accessibility to biological science teachers in secondary schools in Ibadan-north Local Government Area in Oyo State.

2. secondary schools in Ibadan-north Local Government Area of Oyo State.

\subsection{Statement of the problem}

Information and communication technologies are already a vital factor in successful development of education. Education for new emerging societies requires ICT to facilitate more meaningful learning. Information and scientific knowledge are parts of means of improving society, and main products of improving effective teaching and learning. ICT has becomes a critical tool for professional training. The sooner learners know how to use products of ICT, the easier they can find their way to capture the newest still have to fully appreciate the importance of ICT in realizing their teaching objectives, while many may find themselves incompetent to handle ICT as instructional delivery, Okoro (2009). Recently the Federal Government contended that computer knowledge would be a requirement for some employments, interviews and in some cases promotions. Given the constant flux in global, economy and information and communication technology, it is not certain whether the present curriculum of business education can meet the modern and technological demand of teaching the subject all secondary school level, Ikenga; Akiti and Onyemah, (2009).

Despite these efforts of both federal governments accessibility some vital areas of application still appear not attended to in secondary school in Ibadan-north Local Government. From the background information provided above, the need for accessibility and utilization of ICT facilities by the academic in secondary educational system cannot be over emphasized. It is based on this foregoing that the study tend to empirically test utilization of ICT facilities in the teaching of Biological science in selected secondary schools in Ibadan-north Local Government of Oyo State.

\subsection{Research Questions}

For the purpose of carrying this study, two research questions were formulated to guide the study.

1. What is the extent of ICT facilities accessibility to teachers in the teaching of biological science in secondary schools in Ibadan-north Local Government Area of Oyo State?

2. What is the extent of ICT facilities utilization in the teaching of biological science by teachers in secondary schools in Ibadan-north Local Government Area of Oyo State?

\subsection{Hypotheses}

The following hypotheses were tested at 0.05 level of significance:

1. There is no significant difference in the mean responses of male and female biological science teachers on ICT facilities accessibility in the teaching of biological science in secondary schools in Ibadan-north Local Government Area of Oyo State.

2. There is no significant difference in the mean responses of male and female biological science teachers on ICT facilities utilization in teaching of biological science in secondary schools in Ibadan-north Local Government Area of Oyo State. 


\section{Methodology}

This study adopted the descriptive survey design, a total number of 72 biological science teachers were purposively drawn from 25 randomly selected secondary schools in the state, in which 43 were males and 28 were females. A 20 item questionnaires titled Information and Communication Technology Facilities Accessibility Questionnaire (ICTFAQ) and Information and Communication Technology Facilities Utilization Questionnaire (ICTFUQ) were designed for data collection for this study. Hence, respondents were asked to rate each of the items on 4 point likert scale as follows: Strongly Agree (SA - 4 points), Agree (A - 3 points), Disagree (D - 2 points), and Strongly Disagree (SD - 1 point) were used. The instruments were validated by four experts in the faculty of education in the University of Ibadan, Oyo state Nigeria while a splift-half method was used with a pilot group of 12 biological science teachers from neighboring communities in the state to derive the reliability coefficient of 0.86 using the Spearman Brown formula. The questionnaires was administered by the researchers assisted by two research assistants who were specifically trained and instructed on the manner in which the instrument was to be administered. All the 76 packed questionnaire was completed and returned within 2 weeks of administration and used to for the analysis. Hence, the data gathered from the study were analyzed using the mean $(\mathrm{x}$ ) standard deviation as statistical tools. The mean of 2.5 was regarded as "Reject" while a mean response of or above 2.5 were regarded as "Accept" for research questions, while the null hypotheses were tested at 0.05 level of significance such that any calculated t-test value of 1.96 or above at 0.05 level of significance $(P>0.05)$ were regarded as "significant".

\section{Results and Findings}

\subsection{Research Question 1}

What are the extents of ICT facilities accessibility to Biology teachers for the teaching of Biological science in secondary schools in Ibadan North Local Government Area of Oyo State?

Table 1: Means and Standard Deviation Scores of views of Biological science Teachers on ICT Facilities Accessibility in Secondary Schools in Ibadan North Local Government Area in Oyo State

\begin{tabular}{|c|l|c|c|c|}
\hline S/N & ICT Facilities & Mean & Standard deviation & Decision \\
\hline 1 & Internet/web services & 1.24 & 0.429 & Reject \\
\hline 2 & e-mail & 1.12 & 0.332 & \\
\hline 3 & Multimedia projector & 1.76 & 0.421 & \\
\hline 4 & Interactive radio & 1.12 & 0.332 & \\
\hline 5 & Video conferencing & 1.25 & 0.438 & \\
\hline 6 & Audiotapes & 1.77 & 0.422 & \\
\hline 7 & Fax machines & 1.75 & 0.838 & \\
\hline 8 & Computers & 1.75 & 0.838 & \\
\hline 9 & Photocopy machines & 1.12 & 0.332 & \\
\hline 10 & Electronic cameras & 1.79 & 0.421 & \\
\hline
\end{tabular}

In response to research question, table 1 , shows that all the respondents disagreed on the ICT facilities accessibility in the teaching of biological science in secondary schools in Ibadan north Local Government Area of Oyo State. All the 10 items had mean scores below the cut-off point of 2.5 .

\subsection{Research Question 2}

What is the extent of ICT facilities utilization in the teaching of biological science by biological science teachers in Secondary schools in Ibadan north Local Government Area of Oyo State? 
Table 2: Means and Standard Deviation Scores of views of Biological Science Teachers on ICT Facilities Utilization in Secondary Schools in Ibadan north Local Government Area

\begin{tabular}{|c|l|c|c|c|}
\hline S/N & ICT Facilities & Mean & Standard deviation & Decision \\
\hline 1 & Internet/web services & 1.24 & 0.429 & Reject \\
\hline 2 & e-mail & 1.12 & 0.332 & \\
\hline 3 & Multimedia projector & 1.76 & 0.421 & \\
\hline 4 & Interactive radio & 1.25 & 0.438 & \\
\hline 5 & Teleconferencing & 1.77 & 0.422 & \\
\hline 6 & Audiotapes & 1.12 & 0.332 & \\
\hline 7 & Fax machines & 1.05 & 0.220 & \\
\hline 8 & Computers & 1.05 & 0.220 & \\
\hline 9 & Photocopy machines & 1.75 & 0.839 & \\
\hline 10 & Electronic cameras & 1.77 & 0.422 & \\
\hline
\end{tabular}

From the above table teleconferencing and electronic cameras have the highest mean score (1.77), followed by multimedia projector (1.76); photocopy machines (1.75). The rest were 1.25 and below. But notwithstanding the level of utilization is still very low because all the facilities have below 2.5 which is the cut-off point.

\subsection{Hypothesis 1}

Table 3: There is no Significant Difference in the Mean responses of Male and Female Biological Science Teachers on ICT Facilities Accessibility in the Teaching of Biological Science in Secondary Schools in Ibadan north Local Government Area of Oyo State

\begin{tabular}{|c|c|c|c|c|c|c|c|}
\hline Group & $\mathrm{N}$ & $X$ & SD & DF & t-cal value & t-crit. value & Decision \\
\hline Male biological science teachers & 43 & 3.10 & 0.76 & \multirow{2}{*}{64} & 1271 & \multirow{2}{*}{1.960} & \multirow{2}{*}{ NS } \\
\hline Female biological science teachers & 28 & 2.86 & 0.82 & & $1.3 / 4$ & & \\
\hline
\end{tabular}

Table 3 shows that the calculated t-test value of 1.374 is less than the criterion value of 1.960 at 0.05 level of significance. Basically, this implies that the views of both the male and female biological science teachers on ICT facilities accessibility in the teaching of biological science in secondary schools in Ibadan north Local Government Area of Oyo State did not differ. Therefore the null hypothesis 1 is accepted

\subsection{Hypothesis 2}

Table 4: There is no Significant different in the Mean Responses of Male and Female Biological Science Teachers on ICT Facilities Utilization in Teaching of Biological Science by Biological Science Teachers in Secondary Schools in Ibadan north Local Government Area

\begin{tabular}{|l|c|c|c|r|r|r|c|}
\hline Group & $\mathrm{N}$ & $\mathrm{X}$ & $\mathrm{SD}$ & $\mathrm{DF}$ & t-cal value & t-crit value & Decision \\
\hline Male biological science teachers & 43 & 3.11 & 0.78 & 64 & 1.382 & 1.960 & NS \\
\hline Female biological science teachers & 28 & 2.69 & 0.80 & & & \\
\hline
\end{tabular}

Table 4 also shows that the calculated value of 1.382 is less than the criterion value of 1.960 at 0.05 level of significance. Basically, it implies that the views of both male and female Biological science teachers on ICT facilities utilization in teaching of biological science in secondary schools in Ibadan north Local Government Area in Oyo State not differ. Therefore the null hypothesis 2 is accepted

\section{Discussion}

The level of accessibility of ICT resources depends on their availability. The poor availability level of ICT resources in secondary schools in Ibadan north local government of Oyo state also means accessibility will be hindered for teaching and learning. This confirms the observation of Ezeoba (2007) and Fakeye (2010) who also found that ICT resources were not available in primary and secondary schools. 
Ohakwe and Okwuanaso (2006) contented that the knowledge of computer application software's such as spreadsheet, excel, computer - aided design, and database are important skills in teaching and such skills should be impacted. On the recipients of biological science, these would make them to compete confidently and acquire vast knowledge in their education pursuit. The above study supported this current study on the importance of ICT in teachinglearning process. Umaru (2003) and Nworgu (2008) in their studies emphasied that computer aided instruction is a programme of instruction or package presented in software for instructional purpose. They went further to state that ICT made the teaching and learning process efficient, most effective easier and less cumbersome.

Nworgu (2008) further cited Ezeliora (2000) that the use of computer aided instruction provides the learner with different background and characteristics, such background may be in the form of tutorials, drills and practices as well as simulations. For instance, the drills and practices in biological science exposes the students to practical aspect of the learning process that have been carried out previously and which can be graded at the end of the exercise. Nevertheless, Oladeji (2007) in his study also viewed that: there is no basis for comparism between the knowledge provided through the traditional teaching method and that given through information and communication technology. In view of the increasing need for effectiveness, efficiency and continuity, compared with rapid expansion of education and ever increasing need for new technologies, it has become imperative that new entrants into the world of science should be well trained, grounded and prepared.

\section{Conclusion}

It can be concluded from this study that, integration and proper utilization of ICT in the teaching of biological science in secondary schools in the Oyo state will go a long way in raising the fallen standard of education, making learning real and more interesting, no longer abstract. This also will motivate biological science learners, who deserve an improved approach to their daily educational pursuit via the use of modern educational technologies. The need to equip biological science teachers with adequate ICT skills and infrastructure also becomes imperative

\section{Recommendations}

Based on the results and findings of the study, the following recommendations were made, as these recommendations would go a long way to solve the problems of ICT accessibility and utilization in secondary schools in the state.

1. Biological science teachers in secondary schools in the state should be exposed to ICT use in instructional development through seminars and workshops sponsored by the state government

2. Government should concentrate the ICT policies in the secondary schools in the State

3. Where government does not make these available, Parents Teachers' Association (PTA) should find a way of making internal arrangements to generate funds in order to pay the cost of these infrastructures.

\section{References}

Adu, E.O., Adelabu, O. \& Adjogri, S.J. (2014). Information and Communication Technology (ICT): The implications for Sustainable Development in Nigeria. In Proceedings of World Conference on Educational Multimedia, Hypermedia and Telecommunications 2014 (pp. 35-43). Chesapeake, VA: AACE http://www.editlib.org/pv/147482/

Arunachalam, S. (2005). Information and knowledge in the age of electronic communication. A developing country perspective. http//www.bytesford. org/5th/arum.htm

Caselli D (1999). A new trend in the application of information and communication technology in schools. In Langlois, C. (Ed.). Universities and new information and communication technologies: issues and strategies. European Journal of Engineering Education, 23(3): 285-295

Chukwumezie, F.U and Nwogwugwu, P.O. (2007) Computer packages required of graduates secretaries for the promotion of economic empowerment in private organizations. Business Education Journals (VI) 1 Oct.

Eme, O.C. (2007). Reforming the delivery system in business education through ICT. A paperpresented at the national association of business educator (ABEN). Ebonyi.

Ezeoba, K. O. (2007). Instructional Media. An Assessment of the Availability, Utilization and Production by Nursery School Teachers. Journal of Applied Literacy and Reading. 3 (Special Edition) 33-38.

Fakeye, D. O. (2010). Assessment of English Language Teachers' Knowledge and Use of Information and Communication Technology (ICT) in Ibadan Southwest Local Government of Oyo State. American- Eurasian Journal of Scientific Research. 5 (4).56-59.

Holloway, S. \& Valentine, G. (2003). Cyberkids: Children in the Information Age, Routledge, London.

Ikenga, G.U., Akiti, N. \& Onyemah, L.N. (2009). Computer aided instruction (CAl). Strategies in the teaching and learning of business education in tertiary institutions. A paper presented at the 21st annual national conference of the association of business 
educators of Nigeria (ABEN) on the 13th-17th October, 2009 at Abia State polytechnic, Aba, Abia State.

Miller, O. \& Akume, B. S. (2009). The challenges of effective application of ICT aided learning in office technology education. A paper presented at the 21st annual national conference of association of business educators of Nigeria (ABEN) on the 13th -17 th October, 2009 at Abia State Polytechnic Aba, Abia State.

Ndukwe, O. (2006). Furthering the digital revolution in Nigeria in an era of technology convergence. Vanguard Newspaper, Monday 16 Jan., 2006

Nworgu, L.N. (2008). CAI, Strategy for enhancing the effectiveness of scology teaching and learning in the new information age. Journal of Faculty of Education. University of Nigeria.

Nsukka. O. S. \& Okwuanaso, S. (2006). The access centre: improving outcomes for all students K-8

Oladeji, A. (2007). Information and Communication Technology in classroom instruction. Journal of professional teacher trainers (III) 1 \& 2 August.

Tondeur, Valcke \& Van Braak (2008). Towards an acquisition policy of ICTs. In Williams, Marie (Ed.). Using Information Technology Oxford: Heineman Educational Publishers. 